\title{
Outer Enamel Epithelium
}

National Cancer Institute

\section{Source}

National Cancer Institute. Outer Enamel Epithelium. NCI Thesaurus. Code C33232.

Epithelium derived from the ectoderm of the dental lamina. It is found on the upper part

of the bell or cap of the enamel organ of the developing tooth and is composed of cuboidal cells. 